\title{
The South Brisbane Municipal Chambers: A landmark with many pasts
}

\author{
Peter Roennfeldt \\ p.roennfeldt@griffith.edu.au
}

\begin{abstract}
During its 125-year history, the South Brisbane Municipal Chambers (Old Town Hall) has had numerous custodians and functions. Designed as a prominent landmark directly across the Brisbane River from the Queensland Parliament building, its ornate architectural features make it a unique example of late colonial extravagance. With the absorption of the City of South Brisbane into the greater Brisbane City Council in 1925, the building lost its original purpose, but was subsequently deployed in various ways. After serving as a Council Works Depot, it became the headquarters of the US armed forces Military Police during World War II, and was then converted into post-war residential flats for government engineers and architects. Since the late 1950s, 'The Chambers' has been an educational and cultural centre, initially as the first campus of the Queensland Conservatorium of Music, then as a centre for adult learning, and finally now in its completely refurbished form as part of the girls' school Somerville House. This 'building biography' traces the various phases of this iconic landmark from the viewpoint of those who worked, lived or studied there, and also provides insights into its social context within the South Brisbane community.
\end{abstract}

Known affectionately but erroneously as the 'Old Town Hall', the South Brisbane Municipal Chambers has served many purposes over the past 125 years. Until the distinctive edifice was purchased by Somerville House in the late 1990s, it had periodically adapted to the widely contrasting demands of local government and the US Armed Forces. It also served the state Department of Education as a campus of the Queensland Conservatorium of Music and subsequently Technical and Further Education programs. In the meantime, it was also briefly repurposed as living quarters for government employees.

In April 2011, the Brisbane History Group hosted 'Cultural Icons of South Brisbane', a seminar focusing on three adjacent landmarks: the former South Brisbane Library - now Griffith Film School; Memorial Park; and the former Municipal Chambers, hereafter referred to as the 'Chambers'. Bill Metcalf subsequently documented his research into the park and library in this journal, ${ }^{1}$ so this article 
completes the precinct survey. Metcalf has suggested that on its completion in 1892, the Chambers was 'a far more grand building than that to which Brisbane city could lay claim' ${ }^{2}$ - that is, the rival and quite separate municipality north of the river. Its grandeur remains today, despite it having frequently changed hands and been subjected to renovation for a variety of usages.

\section{Planning and construction}

By 1860, (South) Brisbane was a major port for the new colony of Queensland. Because of its transport links to the interior, pastoralists chose the area as a natural city base, with some building grand homes in Highgate Hill. Businesses in Brisbane's division of South Ward and the nearby area of Woolloongabba were not immune from the 1860s recession, but were well poised for the 1880s boom. The local population soared to nearly 23,000 by the time of the 1891 Census, ${ }^{3}$ due to both land availability and a new railway line terminating near the recently opened dry dock, now the Queensland Maritime Museum. The unstoppable momentum towards separation from (North) Brisbane culminated in the creation of the Borough of South Brisbane in 1888.

The civic pride attending the election of the new South Brisbane Municipal Council engendered discussions about its future official premises. Interim meeting venues were found, but a new town hall was urgently required. The June 1889 council meeting determined that 'the site selected should be in the immediate vicinity of the Vulture and Stanley Street intersection'. ${ }^{4}$ This central site was chosen, near the fire brigade station and former Post and Telegraph Office, despite objections from Woolloongabba residents..$^{5}$ A month later, the council decided to purchase from the Reid family the property identified as Subdivisions 2 and 3 of Section 1 of Suburban Allotment 140.6 The previous owner, who had in 1856 bought it from the Crown, was John Graham, namesake of the property's side street. Although not South Brisbane's highest point, this location ensured the building's prominence, particularly when viewed from Government House or the parliament directly across the river. Its relatively high elevation also prevented inundation during the 1893 floods.

Despite dissension among councillors, a government loan of $£ 8,000$ was sought in 1888 to erect a municipal chambers rather than a town hall. The design competition, announced in November $1889,{ }^{7}$ resulted in fourteen proposals. The design 'Simplex', submitted by the well-established firm of John Hall \& Son, was accepted in March $1890 .{ }^{8}$ The staff architect credited with the winning design was a recent arrival in Queensland, John Smith Murdoch (1862-1945). His outstanding career later took him to Melbourne and the new Commonwealth Department of Home Affairs, culminating in 1919 with his appointment as Chief Architect, designing Canberra's Provisional Parliament House and other buildings. Other civic projects included Melbourne's Treasury Place Commonwealth Offices, Brisbane's Anzac Square Building and numerous customs houses, post offices and court houses throughout Queensland. ${ }^{9}$

The civic significance of the construction project provided greater architectural scope than Murdoch's earlier Queensland buildings. ${ }^{10}$ For example, his design of the Sandgate Post Office combined simplicity with functionality, with its polychrome brickwork modestly betraying its Victorian era origins. On the other hand, 
the Chambers' classical proportions, arcading and inclusion of string coursing to define various levels, speak to an 'eclectic historical allegiance'. ${ }^{11}$ The clock tower, for example, may have been inspired by the Aberdeen Harbour Offices built recently by Matthews and Mackenzie, the firm where Murdoch had trained. The architects were cognisant of setting a local precedent, and hoped the Chambers would be 'the means of introducing a new style of ornamental building in Brisbane that would perhaps be the forerunner of many others'. ${ }^{12}$ Whatever its stylistic genesis, consensus is that this building, in Italianate Classic Revival style, remains a unique part of Brisbane's heritage.

Even after tenders were called, dissent persisted within council. In late 1890, Alderman Jones protested that 'the Town Hall they proposed to build was an abortion ... it should cost $£ 50,000$ ' ${ }^{13}$ The successful tender by Abraham James, however, amounted to $£ 6,99915 \mathrm{~s} 5 \mathrm{~d} .{ }^{14}$ James was a Woolloongabba builder and brickmaker who had recently constructed, for John Hall and Son, the Red Brick Hotel on Annerley Road. Meanwhile, Council's loan request of 1888 had stalled, but was finally approved in January 1891 and work began, even though other local government projects were suspended because of the economic downturn. ${ }^{15}$

Construction ceased in mid-1891, with James absconding from Queensland amid claims of unpaid wages, a situation solved by Mayor Arthur Morry personally funding ' 10 s in the $£$ ' for the workmen, a total of $£ 4733$ s 6 d. ${ }^{16}$ New tenders were called, but disagreements between architects and council persisted after construction recommenced in September 1891. John Stewart and Co completed the stone, brick and joinery work, John Campbell the plastering, James Kay the plumbing and gasfitting, J. Lang and Co. the painting and glazing, and Exton \& Gough the leadlight work. ${ }^{17}$ The stone-capping ritual was performed, with little ceremony apart from a few flags, by Mayor Thomas Heaslop on 5 January 1892.18 Due to construction problems, and the late inclusion of boundary walls and gates, the budget blew out to $£ 11,000$, for which additional funds had to be sourced. ${ }^{19}$

The clock's installation was initially delayed due to financial constraints. Meanwhile, the tower's openings were enclosed to mitigate potential water damage. After the proclamation of the City of South Brisbane in October 1903, this final piece of infrastructure was commissioned the following year. The Synchronome Electrical Company supplied an electrically controlled four-dial clock system, which was remarkably accurate and innovative for the time. The clock nevertheless required weekly winding, with 130 manual handle turns. ${ }^{20}$

\section{A civic headquarters and landmark}

Detailed press reports describe the first council meeting hosted in the Chambers in June $1892,{ }^{21}$ and the Mayor's Reception with several hundred invited guests. ${ }^{22}$ On 1 July, Premier Samuel Griffith and other prominent politicians attended a celebratory banquet, illuminated with Chinese lanterns. The Chambers 'looked its best', confirming the view that council was 'in possession of very handsome buildings' ${ }^{23}$ Although the general public was not included in these events, the building's tradition of hosting community groups also began in 1892, when the Homestead Association held meetings there. ${ }^{24}$

The entrance portico and vestibule signified the building's importance. A public counter was accessible from the vestibule, with the accountant's office and strong 


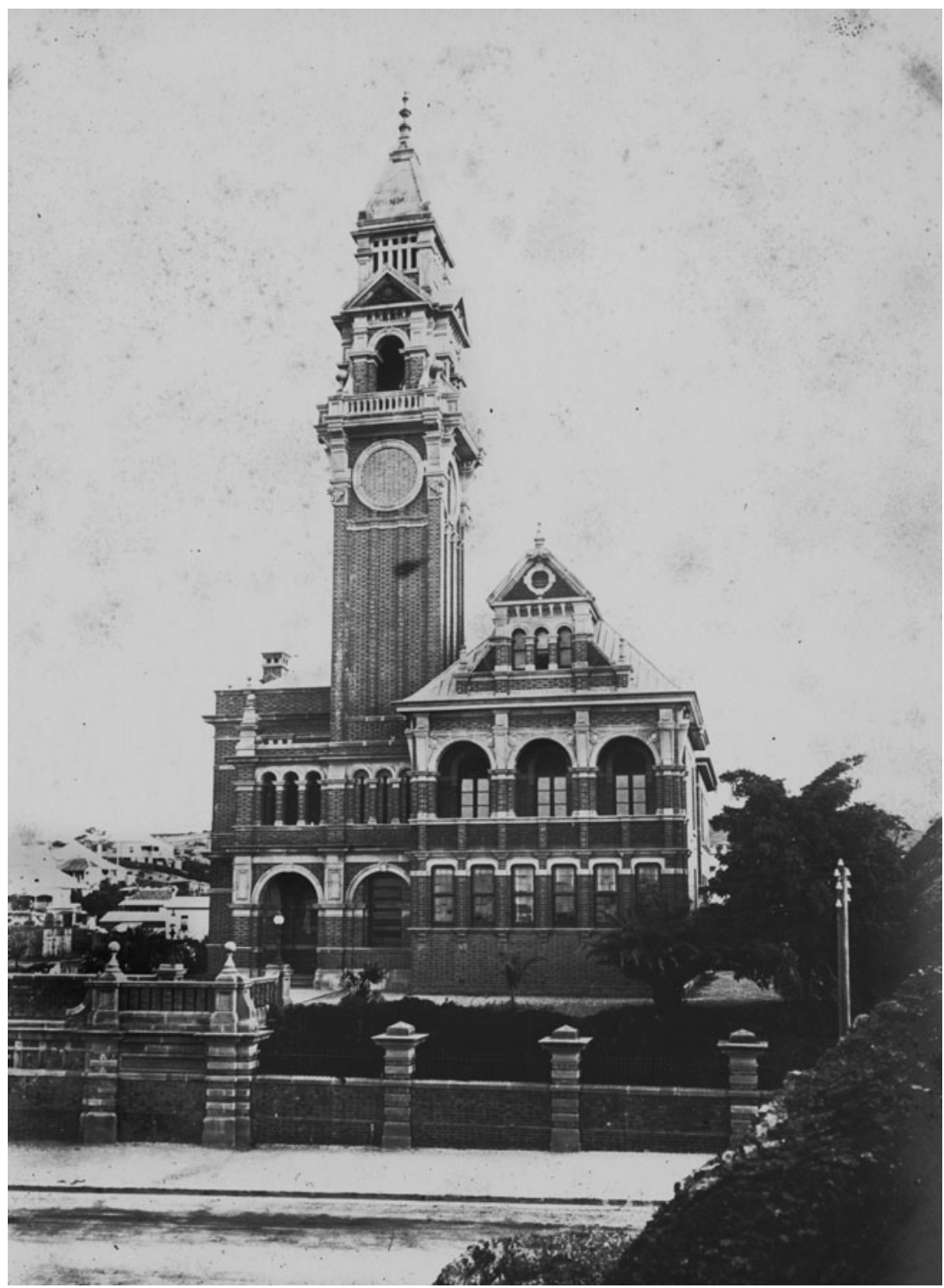

Figure 1

South Brisbane Municipal Chambers before 1904.

Source: State Library of Queensland Negative No. 19890.

room behind. A 1921 photograph shows twenty-five staff, most of whom would have shared workspaces, while only senior officials had their own offices. ${ }^{25}$ Along the Graham Street frontage on the ground floor, the town clerk, mayor and engineer occupied individual rooms furnished with large fireplaces. Along the rear wall was the engineers' drawing office and interconnected rooms for clerks and contractors. A grand marble staircase led to the upper floor and to the three doorways of the council meeting chambers, the largest room in the building. Public observers entered 
the far right door, to view proceedings from behind a moveable barrier. The upper floor's rear section housed the valuator and inspectors, while towards the front were a committee room and aldermen's retiring room. Both front balconies had river views, while upstairs was a storage attic. ${ }^{26}$

Commencing with Thomas Heaslop (1891-93) and ending with John Keogh (1924-25), twenty-five men presided as South Brisbane Mayor from this building. Only six of them served more than one year, though several were also councillors across a longer period. The appointed positions of city clerk and engineer saw less frequent turnover. For example, J. S. Louttit was city engineer from 1896, and J. H. Pampling was clerk from 1919, both serving until the council's dissolution in $1925 .{ }^{27}$

Two events signify the building's iconic status. The signing of the Treaty of Versailles in 1919 was celebrated with a massive 3 mile-long procession through Brisbane, terminating at the Chambers. ${ }^{28}$ These celebrations, sponsored by South Brisbane, were considered a major innovation, since this was the first patriotic procession on the south side. ${ }^{29}$ The building was festooned with blue banners and Allies' flags, and peace doves were released. 'Many thousands' assembled outside, while the mayor invited into the Chambers various military and naval personnel, to be greeted by 130 business leaders. The following year, imperial pride was again displayed, when on 29 July 1920 the Royal Progress of the Prince of Wales, later King Edward VIII, culminated at the Chambers. 'Citizens in their thousands' again appeared, and as before the building was decorated with bunting and a 'gigantic Prince of Wales feather design' on the tower. ${ }^{30}$

The choice of the Chambers as a terminus for such major civic celebrations was logical and strategic. Both sides of the river united in a display of national and imperial pride, and the building's prominent tower facilitated visual spectacles. Ironically, in hindsight, the Prince of Wales's next official engagement after visiting South Brisbane was to lay the foundation stone of the new town hall being built across the river in Albert (later King George) Square. North-south rivalries persisted until 1925, when state government legislation amalgamated over twenty municipalities into the City of Greater Brisbane. Henceforth the Chambers lost its former prominence in civic life. Brisbane's local government bureaucracy would now be focused on its new headquarters, the soon to be completed Brisbane (City) Hall. Although built on a much larger scale, there are architectural similarities with the Chambers, with its Italianate tower and Synchronome clock.

Until the early 1940s, the Chambers was relegated to supporting functions within the newly established Brisbane City Council (BCC). Telephone directories list it as a works depot and office of the district engineer. ${ }^{31}$ From 1926, the city entomologist, Dr Ronald Hamlyn Harris, was based there. ${ }^{32}$ He directed the council's mosquito eradication campaign until 1934, with a research laboratory 'on the roof of the town hall' ${ }^{33}$ The first floor was also used by the Queensland Social Service League during the 1930s: its women's section meetings were being held there until 1940. ${ }^{34}$ This group's major activity was garment making and distribution for those in need, for which numerous young women, working on rotation, were paid by the government. ${ }^{35}$ A 1937 newspaper photograph depicts a sewing demonstration against a backdrop that suggests the main chamber as its location. ${ }^{36}$

As worthy as such causes were, the Chambers was not accorded great prestige by BCC. Thankfully, though, in 1931 it rejected a fanciful redevelopment 


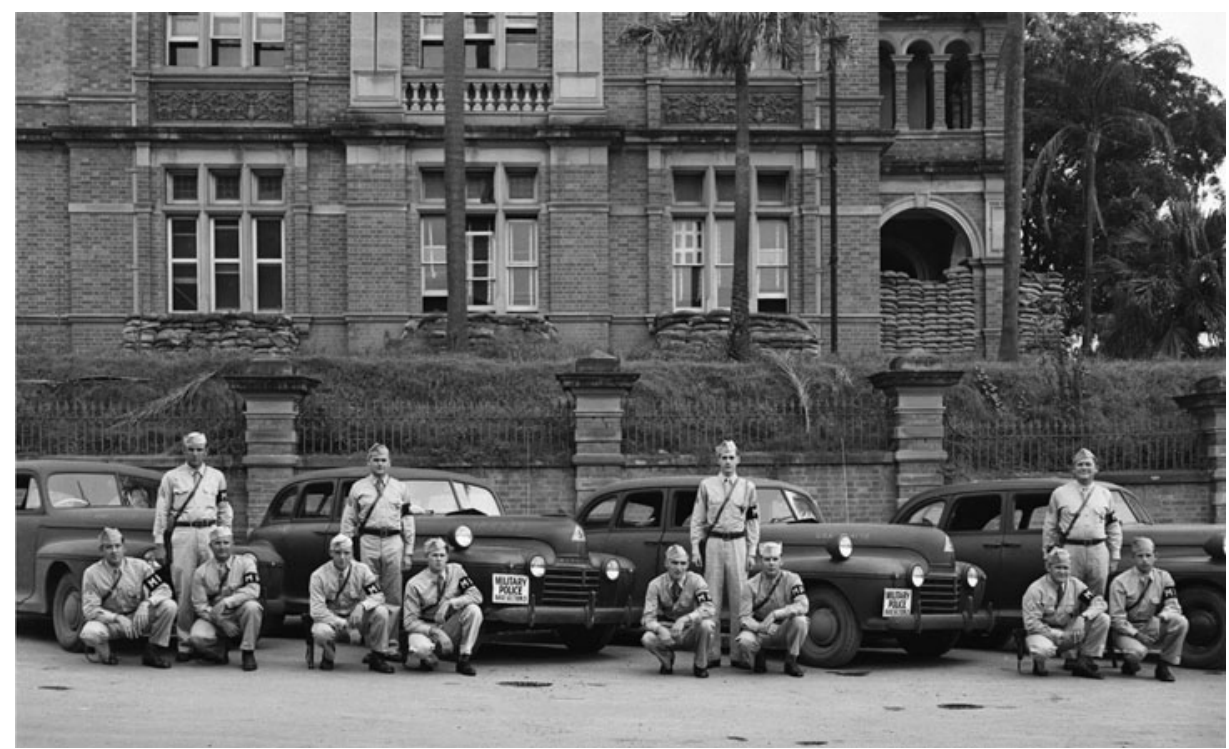

Figure 2

US Military Police in Graham Street outside South Brisbane Municipal Chambers, c. 1944.

Source: Reprinted with permission of National Archives and Records Administration, Washington DC, negative no. 111-SC-350154.

proposal. Despite assurances that its 'present distinctive architectural features' would remain, the impractical possibility of adding 'one or two storeys' had been suggested. ${ }^{37}$

\section{A military incursion}

BCC's Department of Works and Health occupied the Chambers until World War II. In March 1941, the premises were 'urgently required by the authorities for military purposes' ${ }^{38}$ The Australian Military Forces Northern Command offered rental of $£ 58$ 6s $8 \mathrm{~d}$ month. Twelve months later, the Chambers became one of several Brisbane buildings commandeered by the US armed forces preceding General MacArthur's relocation from Melbourne in July 1942. Already by April that year, the 814th Military Police Company was stationed within Base Section No. 3, which covered southern Queensland. The Provost Marshall Office, located within the Chambers, was listed on a register of US-occupied buildings as 'Police and Prison Administration Office', monthly rental $£ 31 .{ }^{39}$ Some of the company's officers were initially billeted 'in a building diagonally across from the South Brisbane Town Hall', ${ }^{40}$ but later moved to a building in Fortitude Valley.

Official photographs depict officers in ground-floor rooms, the exterior protected by sandbags (Figure 2), military police on parade, and a formal interview or possibly court martial proceedings in the council chamber (Figure 3). The busy precinct included the adjacent Somerville House, which served as Base Section headquarters. The military also made some structural changes. With BCC's consent, the existing single-storey garage behind the Chambers was replaced by a two-storey L-shaped wing of brick and fibro cement, for storage and additional 


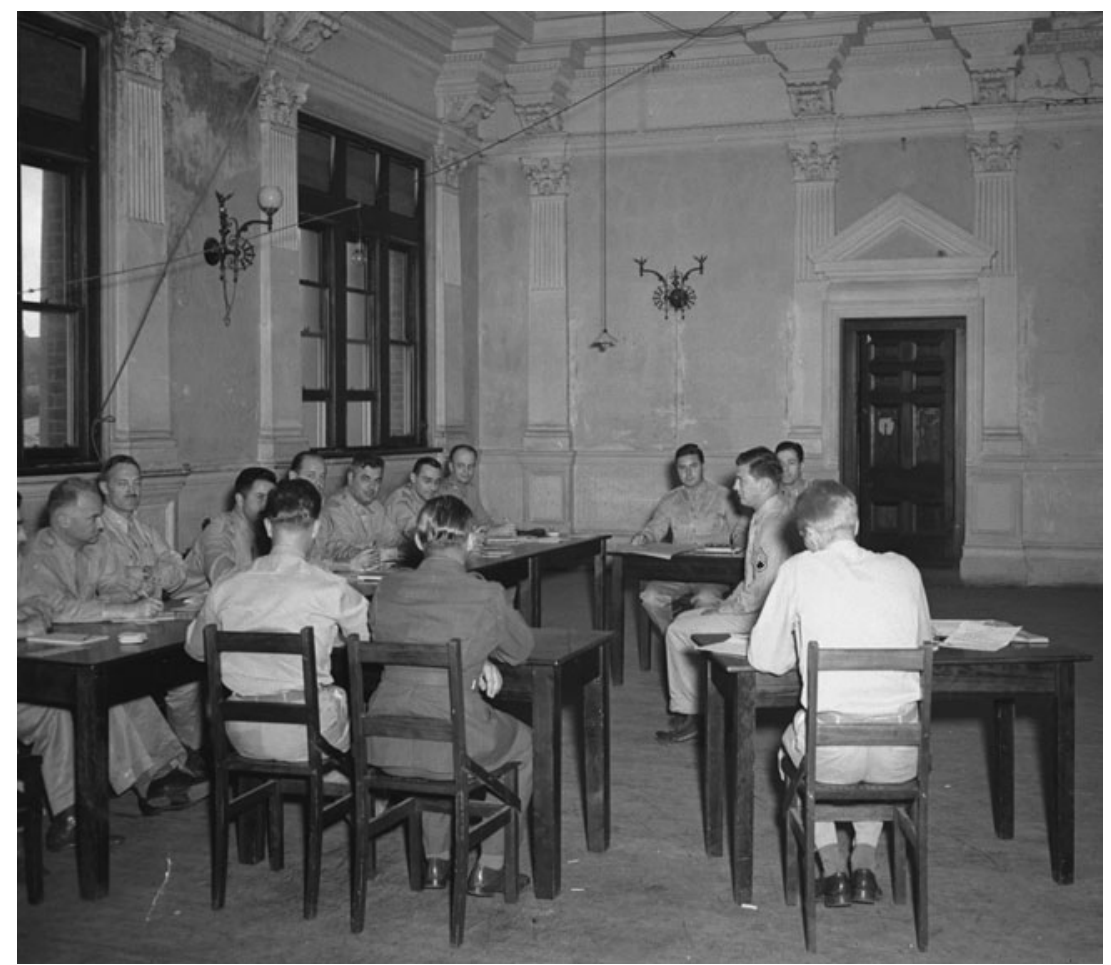

Figure 3

US military personnel in council chamber, c. 1944.

Source: Reprinted with permission of National Archives and Records Administration, Washington DC, negative no. 111-SC-178528.

offices. ${ }^{41}$ A sergeant's memoir indicates that the outbuilding was also used as a dormitory. ${ }^{42}$ Another less well documented change, possibly enacted without BCC's knowledge, was the replacement of the staircase's feature window with a wooden bridge, for easy access to Somerville House. A wartime telephone engineer recalled that air-raid sirens produced a flurry of activity on the exit point of the staircase. ${ }^{43}$

The weekly maintenance visit to the clock tower continued through this period. John (Jock) Johnson was the youngest of three generations of the family who cared for the clock for nearly ninety years. During the war, this required being escorted by 'a soldier with two Colt $45 \mathrm{~s}$ '. ${ }^{44}$ As intimidating as that was, Johnson recalled that the chilling rush of cold air, reputedly caused by a resident ghost, was much more frightening. The so-called basement of the building also had a dark history. In its rear corner was a small room, initially the Council pay office, with a distinctive vaulted brick ceiling. During the war, it was reputedly a solitary confinement cell, ${ }^{45}$ complementing other detention spaces nearby.

Probably the most dramatic event to occur in the Chambers was the court martial of Aveline Fernandez, found guilty of brutally murdering Doris Roberts in a laneway off Elizabeth Street on the night of 19 June 1944. Local detectives investigated, but the trial was conducted as a court martial. When interviewed 
by a local reporter, Fernandez took comfort from the fact that capital punishment was no longer enforced in Queensland, although he was aware that another serviceman had recently been executed in Melbourne's Pentridge Prison. Nevertheless, there was little doubt about his guilt in the Brisbane case, as Fernandez had confessed his crime to Provost Officer Ervin Tash. Since US military law overrode local law in this case, his execution was carried out soon afterwards, but in deference to Queensland sensitivities Fernandez was hanged at Oro Bay, New Guinea.

\section{Housing for civic employees}

Following the war, the Chambers fell vacant, with its future again uncertain. A formal proposal to relocate the South Brisbane Municipal Library there, at a cost of $£ 3,200$, was made in $1946^{46}$ but rescinded the following year. ${ }^{47}$ Meanwhile, squatters were causing a problem that required serving of a Supreme Court writ. ${ }^{48}$ The occupants were three families, including that of former boxing champion Johnny Shields. They cited pressing housing shortages as the reason for taking up an accommodation offer from Ronald Haas, a local Communist Party organiser. Personal possessions in hand, they had not known the whereabouts of their accommodation until arriving at the Chambers in February 1947. ${ }^{49}$ This temporary if illegal residential usage prefigured the Chambers' next major transformation. Town Clerk JC Slaughter recommended its conversion into apartments for housing 'new staff from overseas'. ${ }^{50}$ This included civil engineers and architects recruited to contribute to Queensland's expansion, after a decade of infrastructure stagnation caused by depression and war.

Costing approximately $£ 3,000$, the Chambers was converted into seven flats during mid-1948. One of these was split-level, using the attic as bedrooms connected by an 'extremely narrow staircase', for which an additional emergency exit was required. ${ }^{51}$ While the ground floor layout with large offices and corridors was easily reconfigured, the partitioning of the main council chamber was more radical, including closing in the corner balcony as a kitchen! ${ }^{52}$ All flats had a living room, two bedrooms, kitchen, bathroom and toilet. Average weekly rental was $£ 2$ 7s 6 d, though the split-level flat cost substantially less, and Flat No. 2 slightly more. The rear ground floor flat No. 3 was more spacious, with three bedrooms, and a lounge and dining room instead of just a living room. ${ }^{53}$ Occupied by the architect John Hitch and his Danish wife, this flat housed several items of modernist furniture, which he later claimed were 'in advance of current thinking'. ${ }^{54}$ The juxtaposition of Danish pottery and lampshades and Finnish tapestries with items made with local materials attracted national interest through a feature article in Home Beautiful. ${ }^{55}$ During his residence there, Hitch designed the Ingham Court House and government offices in Rockhampton, which were influenced by Scandinavian modernism. Hitch was the last remaining tenant in 1954 , by when he was lecturing at the University of Queensland and also working in private practice.

The family of civil engineer Alfred Bocker lived in Flat No. 1 near the entrance. The eldest daughter, Veronica, found the building a fascinating place. She recalls playing with a sister and their dolls in the strong room, where formerly cash and official documents were stored. Other highlights were regular basement visits by the 


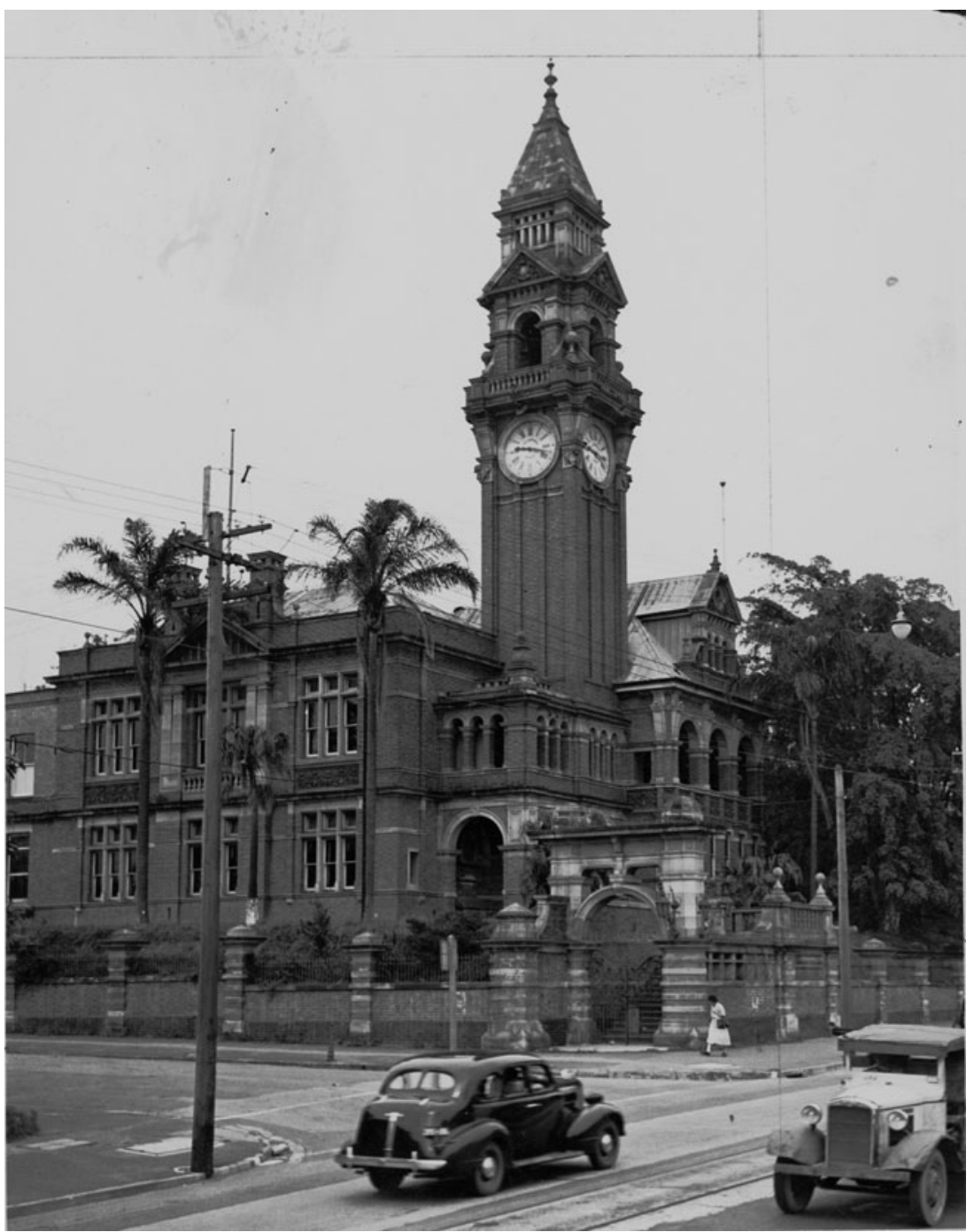

Figure 4

South Brisbane Municipal Chambers 1948.

Source: State Library of Queensland negative no. 33647.

rat-catcher, and being permitted to accompany Jock up the tower, where 'the bit [they] remembered best was the cockroaches crunching under [their] feet on every step! ${ }^{56}$ Upstairs in Flat No. 4 lived the family of Polish architect Mr Kostecki, while the Browns lived in No. 2. Because of its large size, the upstairs council chamber was subdivided and partitioned, as Flats 5 and 6. Probably at this time, false ceilings were inserted, with vertical supports thrust through the chandelier rosettes. This 'improvement' necessitated major repairs over fifty years later.

The former army outbuilding also underwent transformations. During the early 1950s, teenage women desirous of learning dressmaking could gain experience with Moynihans Pty Ltd in its small factory located there. ${ }^{57}$ Experienced frock 
machinists and floor superintendents were also being sought to work at the Graham Street premises, ${ }^{58}$ which were being leased by Noble and Co. for the purpose.

\section{Education - a new purpose?}

Everything changed again in the mid-1950s. The long-running campaign to establish a school of music in Brisbane had faltered frequently, with the lack of buildings often cited as an excuse. In this context, the Chambers emerged as a possibility. ${ }^{59}$ Coincidentally, before its conversion into apartments, the building had in the interim been used briefly for musical purposes, providing storage and rehearsal space for two bands - presumably brass ensembles. Serious consideration was delayed until 1953, when the government implemented its election commitment to proceed with the conservatorium project. In September that year, the Public Service Commissioner recommended the purchase of the Chambers and its rear extension for $£ 40,000$, mentioning its suitability as a music school 'in a good locality with excellent accessibility'. ${ }^{60}$ The sticking point was vacant possession, which was delayed until December 1954. It was then also discovered that the commercial tenant was still occupying the outbuilding. ${ }^{61}$ By 1955, the situation was urgent, but transfer to the State Works Department was delayed further until 30 June. Notwithstanding these pressures, an interim arrangement was made for Noble \& Co. to continue leasing part of the building on a monthly basis.

In April 1955, the government determined that the new institution be named the 'Queensland Conservatorium of Music' and established within the Department of Public Instruction (later renamed the Department of Education). Following acquisition of the building, the Department of Public Works planned its conversion for musical purposes, combining the needs of administration, studio teaching, lectures and performances. Soon after foundation director Dr William Lovelock arrived in June 1956, details of room usage were confirmed. Administration and the director's office were situated near the front entrance, and four teaching studios towards the rear, including one designated as a lecture room. The upper floor featured the lecture/concert hall with a newly built stage leading to an artists' room, two teaching studios and library. Except for some necessary partitioning, the floor plan had reverted to its pre-1947 layout, at a cost of $£ 16,600$.

The original engineer's office, which became the studio of the Conservatorium's first piano lecturer, Rex Hobcroft, had particular memories for one student. On the very spot where lessons were delivered, he used to have dinner with family members when it was Flat No. 2. ${ }^{62}$ As pressures on teaching space increased, even the attic was occupied. Although it was initially considered to be 'quite unsuitable' as quarters for the resident caretaker, ${ }^{63}$ this small space was assigned to part-time staff. Rather inappropriately, this included teachers of larger instruments such as cello, and some requiring deep breathing. Trombone teacher Ron Stevens recalls that often lessons were delayed until the panting students regained their composure, having climbed three flights of stairs clutching their instruments. ${ }^{64}$

The former council chamber was the venue for most student and staff performances, workshops, larger lectures and examinations. In addition to bearing witness to the emergence of many musicians who later forged major careers, this hall heard much repertoire, including several world premières, and was even adapted for opera productions. Press critics noted the sonic interference of passing trams, while 
for audiences and performers the addition of rotary ceiling fans was disturbing, as this also distorted musical sounds.

Despite Premier Vince Gair's claim at the official opening on 16 February 1957 that the new Conservatorium would be 'the best', ${ }^{65}$ students and staff soon realised their building's inadequacies. Studios were poorly soundproofed, exacerbated by sound transference through the mechanical ventilation unit. Similarly, the main hall was not quarantined from sounds emanating from elsewhere, though presumably this abated during performances. With rapidly rising enrolments, chiefly with several hundred part-time students attending during late afternoons and evenings, and a gradual increase in full-time staffing during the 1960s, space was always in critically short supply.

From the early 1960s, the upper floor of the rear annexe building also accommodated the on-site caretaker and their family, particularly after they were forced to evacuate their original premises due to the collapse of the rock wall adjoining Somerville House. ${ }^{66}$ The annexe's ground floor was converted into studios where pianist Nancy Weir and flautist James Carson taught, while other spaces were converted rather unsatisfactorily into lecture rooms, library and a storeroom.

These cramped circumstances were documented in an extensive 1968 newspaper article. ${ }^{67}$ Despite this exposé, no major improvements occurred thereafter, apart from addressing emergencies such as falling ceiling plaster. Another disincentive was the announcement that the Conservatorium would move to a new purposebuilt campus at Gardens Point, adjoining the Queensland Institute of Technology (QIT). Soon after the new campus's official opening across the river in August 1975, the Conservatorium advised the Works Department that it no longer required the South Brisbane building. ${ }^{68}$

For the fourth time in fifty years, the Chambers' future was unclear. Interested parties included neighbouring institution Somerville House ${ }^{69}$ and the National Trust, which was then located in the Rothwells Building, ${ }^{70}$ but a proposal to relocate the John Oxley Library from William Street was given priority. Mooted in late 1971, this proposal received Cabinet approval, ${ }^{71}$ and plans were sketched. However, it was later decided to relocate the library within the Cultural Centre being planned for South Brisbane near Victoria Bridge. Furthermore, it was decided in October 1975 to relocate the Adult Education unit from William Street, and the Guidance and Special Education branch, then at the QIT campus, to the Chambers. ${ }^{72}$ Lengthy inspections, repairs, remodelling and outfitting ensued, costing more than $\$ 200,000 .^{73}$

The building reopened as a branch of the recently renamed Technical and Further Education (TAFE) network, so it again became a community centre. The Guidance and Special Education branch occupied the annexe in early 1977, while Further Education's administration moved into the Chambers in June, although classes did not commence until May $1978 .^{74}$ The floor plan was largely unaltered, other than creating a library out of two rooms on the ground floor. TAFE was justly proud of displaying its refurbishment work during an 'open house' on 21 July 1978, the day after its official reopening by Val Bird, Minister for Education. ${ }^{75}$

TAFE's main focus there was its extension program, particularly leisure and enrichment, adult literacy and numeracy, and special programs for Aboriginal students. ${ }^{76}$ As a throwback to the 1940 s, a gas stove was installed for cooking classes, 
where the kitchen of Flat No. 3 used to exist. The basement which had previously been a Conservatorium common area was used for craft classes, ${ }^{77}$ while the 'cell' was used as a cleaner's storeroom. Other building users were the Genealogical Society of Queensland, Industrial Archaeologists' Association, Wildlife Preservation Society and Queensland Embroiderers' Guild. ${ }^{78}$ An Aboriginal and Torres Strait Islander Education Unit was also briefly housed in the annexe. ${ }^{79}$

During its tenure at the Chambers, TAFE programs expanded greatly. Commencing with over 200 courses and 50 classes per week, by 1992 it was operating seven days a week with approximately 8,000 students enrolled. ${ }^{80}$ This inevitably caused much wear and tear, but one positive reminder of this phase was the project to recreate the staircase's lost stained glass window, based on early sketches. Glass artist Bob Myles was commissioned, and his work received a commendation by the National Trust, under its John Herbert Award for Excellence in Heritage Conservation. ${ }^{81}$

In 1999 the Chambers again changed hands, probably for the last time. The girls' school Somerville House had since 1920 stood nearby on Mater Hill, initially using historic 'Cumbooquepa' on Vulture Street as its boarding house. After 'many "near misses" and frustrated attempts', acquisition of the Chambers now seemed possible in 1998, when Southbank TAFE announced cessation of its classes there. ${ }^{82}$

Purchase of the Chambers in June 1999 by Somerville House fulfilled a long-held ambition for the school, but it was not without controversy. The visual synergy of the Vulture Street aspect of several adjacent heritage buildings suggested that they belonged together. Educational connections also existed, as a number of past students had regularly visited the Chambers for their Conservatorium lessons. The Kurilpa Protection Society, a local residents' group, opposed the sale on the basis of the Chambers' history as a public facility. The Public Works and Housing Minister Robert Schwarten was quoted as saying the lack of funds to service the building's ongoing needs, together with Somerville House's strong interest, confirmed that sale was the preferred option. Representing the BCC, the Chambers' former owner, Councillor Tim Quinn, expressed disappointment about the lack of consultation, but admitted that Somerville had good credentials and experience in heritage preservation. ${ }^{83}$

\section{Heritage preservation and cultural significance}

Following inclusion in registers of both the National Trust in 1984 and the Australian Heritage Commission in 1989, and governed by the Queensland Heritage Act in 1992, it was self-evident that any future owner of the Chambers would have immense responsibilities in perpetuity. With approval from the Queensland Heritage Council in 2001, ${ }^{84}$ and based on the conservation plan prepared by Adam Lovell Architects ${ }^{85}$ and a landscape heritage report prepared by Catherine Brouwer Landscape Architects, ${ }^{86}$ the restoration project was completed five years later.

The official reopening of the Chambers occurred in February 2006, and since then the building has hosted various school offices and special events. Following the rear annexe's demolition in 2011, further campus improvements included integrating the Graham Street frontage into the forecourt envisaged for the new Queensland (Lady Cilento) Children's Hospital. ${ }^{87}$ For 'The Chambers', as it is known within Somerville House circles, this meant enhanced integration with the campus, and 
also refurbishment of its basement as a café, known as 'Under The Clock', which opened in late 2014.

Recent developments again brought into focus the Chambers' heritage values and cultural significance. These include its being 'landmark physical evidence' of the growing former Borough of South Brisbane and the 'most substantial and ornate' municipal chambers in Brisbane. It was also the first local building designed in 'free classical style' and the first in Australia to incorporate an electrically driven clock system. Its 'landmark and aesthetic qualities' within the South Brisbane Memorial Park precinct, and significance as an early work by John S. Murdoch, were recognised, as well as the wartime association with the US military. ${ }^{88}$ The clock tower's distinctive campanile design may typify many Italian towns, but the Chambers has been a unique Brisbane landmark ever since it was built, holding its own alongside recent high-rise developments nearby.

The building's architectural qualities are extensively detailed in the National Trust's 1971 publication featuring forty Australian sites, for which the Chambers was selected as one of only six Queensland case studies. ${ }^{89}$ A centenary publication by TAFE staff in 1992 includes oral history anecdotes and newspaper reports, in addition to a chronological survey. ${ }^{90}$ These thematic accounts are invaluable, but they do not completely capture the significance the Chambers holds for its many occupants and visitors, or how parts of the building changed character over time.

\section{Final observations}

Through public amenity and service provision, including governance, town planning, disease and vermin eradication, and occasionally as a backdrop for civic events, the Chambers proved its functionality and versatility quite early. The wartime and post-war phases are historical anomalies, but somehow the Chambers was able to accommodate foreign servicemen including some malcontents, and was even briefly used by squatters. As living quarters for several newcomers with architectural and engineering skills, its post-war residents were living inside one of Queensland's greatest examples of late colonial extravagance, in turn created by an eminent early Australian architect.

While plans for conversion to a library proved impractical, various welfare organisations, community groups and small businesses have also found a temporary base there. The Chambers' transformation into an educational centre, for music, adult learning and now as part of a large school, is probably its most significant contribution. Its recent half-century or more is imbued with an ethos of selfdevelopment on the part of its students, and more broadly as a small but significant cultural hub.

If only walls could talk, the Chambers' full story could be documented more fully. It embodies so many pasts and permutations but it transcends its chequered history, particularly now in its permanently refurbished state. It seems that only incoming custodians are resourced with budgets for improvements and repairs, but not all prior renovations have had lasting benefit. Future occupants and visitors cannot fail to be impressed by the Chambers. As Alain de Botton states, 'we look to our buildings to hold us, like a kind of psychological mould, to a helpful vision of ourselves'. ${ }^{91}$ An intriguing building such as the South Brisbane Municipal Chambers 
will constantly be reinterpreted by those who spend time there, or merely pass by en route to some other less distinctive destination.

\section{Acknowledgements}

The generous assistance of Ms Kate Bottger, Archivist of Somerville House, including the provision of numerous documents and photographic images, is gratefully acknowledged, as well as the information provided by former students Veronica Burningham née Bocker and Majorie Schackleton.

\section{Notes}

1 Bill Metcalf, 'South Brisbane Memorial Park: A memorial to what?', Queensland Review 18(1) (2011): 54-72; Bill Metcalf, 'South Brisbane's cultural hub: From Post and Telegraph to Griffith Film School', Queensland Review 19(2) (2012): 217-33.

2 Metcalf, 'South Brisbane Memorial Park': 56.

3 The Queenslander, 8 August 1891, 278.

4 South Brisbane Municipal Council Minutes 25 May 1888 to 27 October 1890, p. 297.

5 For a complete discussion of these buildings around the time of the planning of SBMC, see Metcalf, 'South Brisbane's cultural hub': 217-18.

6 SBMC Minutes, 25 May 1888 to 27 October 1890, p. 475.

7 Brisbane Courier, 6 November 1889: 7.

8 SBMC Minutes, 25 May 1888 to 27 October 1890, p. 473. For more information about the Hall family of architects, see Donald Watson and Judith McKay, Queensland architects of the 19th century: A biographical dictionary (Brisbane: Queensland Museum, 1994), 84-92.

9 David Rowe, 'John Smith Murdoch: Early Commonwealth Government Architect of Australia', Proceedings of the 1993 Annual Conference of Society of Architectural Historians Australia and New Zealand (Perth: SAHANZ, 1993). See also Watson and McKay, Queensland architects, 127-9.

10 Murdoch's brief tenure with John Hall and Son, which lasted until 1893, also included Woolloongabba's Broadway Hotel, but his first Australian-designed building was the Sandgate Post Office, created in 1887 while he was employed by the Department of Works and Mines.

11 Rowe, 'John Smith Murdoch', p. 4.

12 Rowe, 'John Smith Murdoch', p. 4.

13 Southern World, 3S December 1890, 5.

14 SBMC Minutes, 3 November 1890 to 18 April 1893, p. 25.

15 Southern World, 31 January 1891, 2.

16 Southern World, 12 September 1891, 2.

17 Brisbane Courier, 6 June 1892, 7.

18 Brisbane Courier, 6 January 1892, 6.

19 SBMC Minutes, 3 November 1890 to 18 April 1893, pp. 369-70.

20 Geoffrey Bianchi, Anthony Roberts, John Gardner, John Woolrych and Norman Heckenberg, Synchronome Brisbane 1903-1991: The story of the Jackson family of electrical clock makers (Brisbane: National Association of Watch \& Clock Collectors Queensland, 1998), 19-20.

21 In particular, Brisbane Courier 6 June 1892: 1 and Southern World 8 June 1892: 2. 
22 Southern World 29 June 1892: 2.

23 Brisbane Courier, 2 July 1892: 5.

24 Southern World, 4 June 1892: 2.

25 State Library of Queensland, negative no. 195078.

26 John Hall and Son Architects, Plans for proposed new municipal offices South Brisbane, 1890. Queensland State Archives Item ID 328586, Architectural plans.

27 F. J. Brewer and R. Dunn, The municipal history of South Brisbane (Brisbane: Pole, 1925), p. 13.

28 Program of Commonwealth Peace Celebrations - Grand Procession Brisbane, 19 July 1919 , p. 1.

29 Brisbane Courier, 21 July 1919, 7.

30 Brisbane Telegraph, 30 July 1920, 2.

31 Brisbane Telephone Directories, 1926-35.

32 Brisbane Courier, 14 June 1926, 7.

33 Brisbane Courier, 18 February 1932: 16.

34 Courier-Mail, 23 July 1940, 10.

35 Queensland Figaro 24 October 1931, 9.

36 Brisbane Telegraph, 2 June 1937, 2.

37 Brisbane City Council Minustes, 1931, 258.

38 BCC Minutes, 1940-41, 455.

39 'Headquarters Base Section No. 3 - Office of the Base Section Register'. Copy of undated document held by Somerville House Archives.

40 Letter from George Pederson to Helen Bennett, 24 January 1991. Document held by Somerville House Archives.

41 BCC Minutes, 1942-43, 211-12.

42 Memoirs of Ray Logue, 1993. Document held by Somerville House Archives.

43 B. K. McKeering, A gracious lady: The South Brisbane Municipal Chambers (Brisbane: South Brisbane TAFE, 1992), pp. 12-13.

44 Rachel Gubby, 'Time to wind up, after one last visit to the haunted tower', Courier-Mail, 15 October 1988: 5.

45 Peter Dunn, 'Office of the Provost Marshall Base Section No. 3 - South Brisbane Municipal Chambers' (2006), pictorial webpage: http://www.ozatwar.com/usarmy/provostbs3.htm.

46 BCC Minutes, 1946-47, 314.

47 BCC Minutes, 1947-48, 629.

48 BCC Minutes, 1946-47, p. 445.

49 Brisbane Courier, 22 February 1947, 5.

50 BCC Minutes, 1947-48, 629-30.

51 BCC Minutes, 1948-49, 38.

52 Department of Public Works, South Brisbane Town Hall - Conversion to Conservatorium of Music, June-September 1955, Queensland State Archives Item ID 578342 — ID 578342 inclusive, Architectural plans.

53 It is possible that Flat No. 3 was the one that attracted the highest weekly rental, rather than No. 2. 
54 John Hitch, John Hitch: Record of a life in architecture (Mt Macedon: John Hitch, 2002), p. 87.

55 Mary Jane Seymour, 'They live in the old Town Hall', Australian Home Beautiful (April 1950): 22-3, 49.

56 Veronica Burningham née Bocker, personal memoir 1999, held in Somerville House Archives.

57 Courier-Mail, 22 October 1954, 16.

58 Courier Mail, 23 June 1954, 15; Telegraph, 1 October 1953, 23.

59 Peter Roennfeldt, Northern Lyrebird: The contribution to Queensland's music by its Conservatorium (Brisbane: Australian Academic Press, 2012), 18. For a complete discussion of the Conservatorium's occupancy of SBMC, see pp. 22, 27-8, and Chapter 2, 38-65.

60 Public Service Commissioner's Department, Minute of 8 September 1953, QSA Item ID 130342.

61 Public Curator, Memorandum to Department of Public Works Under Secretary, 22 February 1955, QSA Item 130342.

62 Rex Hobcroft, 'Confounded Consequences' (unpublished typescript, 2006), p. 137.

63 GW Murphy on behalf of Education Director-General H. G. Watkin, memorandum to Public Works Under Secretary, 23 January 1957, QSA Item ID 130342.

64 Ron Stevens, interview with author, 7 April 2010.

65 Sunday Mail, 19 February 1957, 8.

66 Courier-Mail, 10 February 1962, 7.

67 Sunday Mail, 24 November 1968, 2.

68 Noel Milliken Conservatorium Registrar, letter to Department of Public Works Under Secretary, 17 October 1975, QSA Item ID 601639.

69 Department of the Public Service Board, Memorandum 1 April 1975, QSA Item ID 601639.

70 John Herbert President National Trust of Queensland, letter to Minister for Works and Housing, 22 March 1973, QSA Item ID 130342.

71 Public Service Board Chairman, Proposal to State Cabinet, 12 November 1972, QSA Item ID 60163.

72 Public Service Board Chairman, Memorandum 19 January 1976, QSA Item ID 601639.

73 Department of Public Works, Memorandum 28 November 1977, QSA Item ID 601638.

74 McKeering, A gracious lady, 22, 24.

75 Courier-Mail, 19 July 1978: 18.

76 McKeering, A gracious lady, 33.

77 Department of Public Works, Old Town Hall South Brisbane Department of Education — Adult Education 1975-1954, QSA Item ID 168442-ID 1684431 inclusive, Architectural plans.

78 Brisbane Telegraph, 13 December 1978, 78.

79 R. S. Warry, Department of Education, Memorandum to Department of Public Works 21 May 1984, QSA Item ID 601638.

80 McKeering, A gracious lady, 28.

81 National Trust of Queensland Journal (June 1987), 6.

82 Somerville House Newsletter 18/99 (16 June 1999), 1.

83 Southern South News, 17 June 1999, 1. 
84 Letter from Queensland Government Environmental Protection Agency to Adam Lovell Architects, 29 October 2001.

85 Adam Lovell Architects, Former South Brisbane Municipal Chambers: A conservation plan for Somerville House (Brisbane, 2001).

86 Catherine Brouwer Landscape Architects, Former South Brisbane Municipal Chambers Landscape Heritage Report (Brisbane, 2004).

87 Andrew Ladley Architect, Somerville House and the former South Brisbane Municipal Chambers -Cultural heritage impact assessment report for proposed building and landscaping works (Brisbane, 2012).

88 Ladley, Somerville House, p. 6.

89 D. H. Phillips, 'Town Hall South Brisbane' in Historic Public Buildings of Australia (Melbourne: Cassell, 1971), 282-7.

90 McKeering, A gracious lady.

91 Alain de Botton, The Architecture of Happiness (Melbourne: Penguin, 2006), 107. 